\title{
PHYTOCHEMICAL IDENTIFICATION AND ANTIOXIDANT ACTIVITY OF JUWET FRUIT (Syzygium cumini L. Skeels) ETHANOLIC EXTRACT
}

\author{
I Made Parama Nanda Mahatya ${ }^{1}$, I Gede Putu Wirawan ${ }^{1 *}$, I Ketut Suada ${ }^{1}$ \\ ${ }^{1}$ Faculty of Agriculture, Udayana University, Jalan PB Sudirman Denpasar, Indonesia \\ *Corresponding Author: igpwirawan@unud.ac.id
}

\begin{abstract}
Juwet (Syzygium cumini L. Skeels) is one of Indonesia's local fruits which its existence is hard to find now. All parts of this plant can be used for many treatments, one of which is as an antioxidant. The purpose of this study was to determine the compounds contained in the fruit and to determine the antioxidant activity as well. Phytochemical analysis was performed using the gas chromatography while antioxidant activity tests were carried out quantitatively by DPPH method. The results showed that the juwet fruit was contained phenol $284.47 \mathrm{mg} / 100 \mathrm{~g}$ GAE, flavonoids $379.07 \mathrm{mg} / 100 \mathrm{~g}$, tannins $3888.67 \mathrm{mg} / 100 \mathrm{~g}$ TAE and anthocyanins 40.28 $\mathrm{mg} / 100 \mathrm{~g}$ which consisted of 66 types of chemical compounds. The results of the antioxidant analysis showed that the ethanolic extract of juwet fruit could inhibit DPPH radicals with $\mathrm{IC}_{50}$ of $72,96 \mu \mathrm{g} / \mathrm{ml}$.
\end{abstract}

Keywords: Juwet fruit, antioxidant, phytochemical, DPPH.

\section{INTRODUCTION}

Indonesia is one of the countries that has the highest diversity of medicinal types in the world. This is due to the Indonesian territory is crossed by the equator and has a relatively stable climate which directly affects tropical forests biodiversity. Indonesia's tropical forest areas has the second-highest biodiversity in the world after Brazil's. Experts estimate that no less than 25,000 types of flora grow and spread throughout Indonesia (Primarck et al., 1998), one of which is juwet (java plum) fruit.

Juwet fruit is tasted sour and has oval shape. There are several color types of mature juwet fruit, including black, red, and white. In general, Bali's juwet fruit is consumed freshly as salad. According to Swami et al. (2012) juwet fruit can be used as traditional medicine for diabetes mellitus, anti-inflammation, and antidiarrhea.

Secondary metabolites commonly present in all types of plants are phytochemicals that play a role in body defence against biotic and abiotic disorders is also found in juwet fruit. For human needs, such metabolites are being sought and developed for a variety of benefits, therefore it is important to know the content of secondary metabolites of the juwet fruit. The method used to determine the metabolite content of plants is phytochemical analysis. 
Isolation and identification of phytochemical compounds of juwet fruit can be carried out through extraction methods, phytochemical screening, analysis using gas chromatography (GC), and testing of antioxidant activity using DPPH. Extraction is the process of separating a substance based on the differences of its solubility in two different insoluble liquids.

A maceration system as cold method is usually used to extract the metabolites. Maceration is an extracting process conducted in room temperature and consist of maintaining contact between the plant powder and the solvent for a period of time. Solvent used in this study was $96 \%$ ethanol, not only because it is a volatile polar compound which suitable to use as an extracting solvent, however the ethanol is easy to be obtained and used.

\section{MATERIALS AND METHODS}

\section{Place and Time of the Research}

This research was conducted from March 2020 to June 2020. Juwet fruit was collected from Dauh Peken Village-Tabanan which its temperature was $28^{\circ} \mathrm{C}$, on elevation of 143 meters above sea level, and its coordinate is $(-8.52637 ; 115.1204183)$. The research sample analysis was conducted in the Laboratory of Genetic Resources and Molecular Biology of Udayana University and Analytical Laboratory of Udayana University.

\section{Materials and Tools}

The materials used in this study was black mature of juwet mesocarp (the fleshy middle layer of the fruit pericarp). The tools used were gas chromatography (GC), spectrophotometry, beaker glass, blender, cork borer, erlenmeyer, measuring cup, inoculation needle, camera, label paper, autoclave, filter paper, laminar airflow cabinet, oven, petri dish, micropipettes, test tubes, electric scales, vacuum rotary evaporators, and other equipment used in laboratories.

\section{Preparation of test materials}

Fresh juwet fruit was washed under running water, then separate the seeds to take the mesocarp, and cut into medium size using a knife. Then, dried the sample in the oven for $3 \times 24$ hours with the temperature of $50^{\circ} \mathrm{C}$. Furthermore, the dried juwet fruit was ovendried at $40^{\circ} \mathrm{C}$ to obtain the constant weight (Tapotubun, 2018). Finally, the dried juwet was grinded into powdered using a cutting machine.

\section{Exraction}

Extraction of the juwet fruit was carried out using maceration as follows: $150 \mathrm{~g}$ of finely juwet powder was macerated using two litres of ethanol $96 \%$. The maceration process were carried out at room temperature for three days with regular shaking (Senja et al., 2014). After the filtration, the organic solvent was evaporated under vacuum 
evaporator with the temperature of $40^{\circ} \mathrm{C}$ to obtain crude extract (Putranti, 2013).

\section{Gas chromatography analysis}

The juwet fruit extract was analysed according to the GCMS procedure of the Forensic Laboratory Denpasar. The analysis was carried out using Agilent 7890B MSD 5977B, with the Wakosil ODS/5C18-200 silica column with a size of $4.6 \times 200 \mathrm{~mm}$ using $\mathrm{N}_{2}$ gas as a carrier. The injection temperature used was $290^{\circ} \mathrm{C}$ for 27 minutes with an injection rate of $1 \mu \mathrm{l} /$ minute. Identification was done by comparing the retention time of each chromatograph peak with the database.

\section{Phytochemical Screening \\ Quantitative test}

Phytochemical screening was carried out by using the UV Spectrophotometry method to analyse the composition of a sample quantitatively based on the interaction between the material and light.

Determination of the Total Anthocyanin Contents

Anthocyanin content analysis was carried out using the $\mathrm{pH}$ differential method (Giusti et al., 2001). The first solution was dissolved in $0.025 \mathrm{M} \mathrm{KCl}$ buffer with the $\mathrm{pH}$ of 1.0 and the other solution was dissolved in $0.4 \mathrm{M}$ sodium acetate buffer with the $\mathrm{pH}$ of 4.5. Prior of the test, scanning of sample also carried out by measuring sample in the wavelengths of 200-750 $\mathrm{nm}$ range of both buffers ( $\mathrm{KCl}$ and sodium acetate) to determine the anthocyanin contents and the $\lambda$ vis-max of sample.

\section{Determination of the Total Tannins Contents}

Sample of $500 \mathrm{mg}$ was placed into a flask, then add $50 \mathrm{ml}$ of distilled water and stir with a mechanical shaker for 1 hour. After a filtration, placed the filtrate in a volumetric flask and adjusted by adding water into the volume of $50 \mathrm{ml}$. A volume of $5 \mathrm{ml}$ of filtrate mixed by $0.8 \mathrm{ml}$ of potassium hexacyanoferrate (III) $0.008 \mathrm{M}$ in $0.1 \mathrm{~N}$ hydrochloric acid and $0.8 \mathrm{ml}$ of ferric chloride of $0.1 \mathrm{M}$ in $0.1 \mathrm{~N}$ hydrochloric acids. The absorption of the solution was measured using an ultraviolet-visible spectrophotometer at a wavelength of $420 \mathrm{~nm}$.

Determination of the Total Phenolic

\section{Contents}

Determination of phenolic content in the ethanol extract of juwet refers to the Chun et al. (2003) procedure. The sample of $10 \mathrm{mg}$ was mixed with $10 \mathrm{ml}$ ethanol, then $1 \mathrm{ml}$ of the sample was mixed with $0.4 \mathrm{ml}$ of FolinCiocalteau's reagent. Shake the solution and incubated for 4-8 minutes. The solution was added with $4.0 \mathrm{ml}$ of $\mathrm{Na}_{2} \mathrm{CO}_{3}$ and shaked to homogenize the solution mix, then added with distilled water up to $10 \mathrm{ml}$. The solution incubated for 2 hours and the absorbance was measured at a wavelength of $750 \mathrm{~nm}$ which gave a blue complex. The repetition was done 
three times to obtain the phenol content as mg gallic acid equivalent/g/extract.

\section{Determination of the Total Flavonoids}

\section{Contents}

Put $10 \mathrm{~g}$ of the sample into an erlenmeyer and dissolved with $100 \mathrm{ml}$ of $80 \%$ methanol-water at room temperature for 24 hours. Then the whole solution was filtered and transferred into a crucibles, and evaporated to dry on a water bath and then weighed.

\section{Determination of Antioxidant Activity}

The quantitative test was carried out using the DPPH method. Activity of the extract to free radical was evaluated using a 2,2-diphenyl-1-picrylhydrazyl (DPPH) free radical which provided a strong absorbent at $516 \mathrm{~nm}$. Samples and standards dissolved in ethanol were added with DPPH solution with a volume ratio of $1: 1$ and incubated for 30 minutes at room temperature using a covered dark container lined with aluminium foil. The DPPH absorbent percentage was calculated using a formula: $\mathrm{I}(\%)=($ Ao-As $) /$ Ao $\times 100 \%$, which $\mathrm{I}=$ percentage of decrease of DPPH absorbent, Ao = absorbance of DPPH control solution, and As = absorbance of the sample solution after adding DPPH. Antioxidant activity was expressed by the $\mathrm{IC}_{50}$ value obtained from the linear regression constructed by data of 5 different extract concentrations. The $\mathrm{IC}_{50}$ value was determined as the concentration that cause inhibition of 50\% DPPH (Ghasemi et al., 2009).

\section{RESULTS AND DISCUSSION}

\section{Analysis of Juwet Fruit Extract}

Gas chromatography (GC) analysis produced 66 types of compounds. Literature studies indicated that each compound has its use and function. The compounds were distinguished over its retention time. At the retention time of 2.486 was found d-glycerod-glacto-heptose compound and its function is involved in the biosynthesis of lipopolysaccharide by G-negative bacteria (Mayer and Tanner, 2007). At the retention time of 3.176 found carbonodithioic acid and S-ethyl 0-(1-methyl ethyl) ester which acting as an antioxidant (Lauderback et al., 2009), while at the retention time of 3.640 was methyl compound such as gamma-octalactone ( $\mathrm{Z}$ and $\mathrm{E}$ ) which acts as an antineoplastic agent and antibacterial agent (PubCham, 2020).

\section{Phytochemical Quantitative Analysis}

\section{Screening results.}

The phytochemical analysis found 4 phytochemical compounds contained in the ethanolic extract of juwet fruit flesh, namely phenolic compounds, flavonoids, tannins, and anthocyanin as shown in Table 1. The phenol content obtained was expressed as an equivalent to $\mathrm{mg}$ of gallic acid/100 $\mathrm{mg}$ of a fresh sample. 
Table 1. Phytochemical analysis of juwet fruit

\begin{tabular}{cccccc}
\hline No & $\begin{array}{c}\text { Sample } \\
\text { code }\end{array}$ & $\begin{array}{c}\text { Total } \\
\text { phenolic } \\
\text { content } \\
(\mathrm{mg} / 100 \mathrm{~g} \\
\mathrm{GAE})\end{array}$ & $\begin{array}{c}\text { Flavonoid } \\
(\mathrm{mg} / 100 \mathrm{~g})\end{array}$ & $\begin{array}{c}\text { Tannin } \\
\text { content } \\
(\mathrm{mg} / 100 \mathrm{~g} \\
\text { TAE })\end{array}$ & $\begin{array}{c}\text { Anthocyani } \\
\text { n content } \\
(\mathrm{mg} / 100 \mathrm{~g})\end{array}$ \\
\hline 1 & $\begin{array}{c}\text { Extract of } \\
\text { flesh fruit } \\
\text { of juwet }\end{array}$ & 284.47 & 379.07 & 3888.67 & 40.28 \\
& & & & \\
\hline
\end{tabular}

Table 2. Antioxidant activity of the juwet extract

\begin{tabular}{ccccc}
\hline Absorbance & $\begin{array}{c}\text { Extract } \\
\text { concentration } \\
(\mu \mathrm{g} / \mathrm{ml})\end{array}$ & $\begin{array}{c}\text { Decreasing } \\
\text { absorbance, } \mathrm{I} \\
(\%)\end{array}$ & $\begin{array}{c}\text { Regression } \\
\text { equation } \\
(\mathrm{y}=\mathrm{bx}+\mathrm{a})\end{array}$ & $\mathrm{IC}_{50}(\mu \mathrm{g} / \mathrm{ml})$ \\
\hline 0.453 & Blank & 0 & & \\
0.236 & 0.2 & 47.9029 & $\mathrm{y}=40.839 \mathrm{x}+$ & 72.96947 \\
0.134 & 0.4 & 70.4194 & 47.02 & \\
0.115 & 0.6 & 74.6137 & & \\
0.084 & 0.8 & 8.457 & & \\
0.076 & 1 & 8.223 & & \\
=\% inhibition, $\mathrm{a}=$ constant, $\mathrm{b}=$ gradient, $\mathrm{x}=\mathrm{DPPH}(\mu \mathrm{g} / \mathrm{ml}), \mathrm{IC}_{50}=$ effective concentration \\
gainst 50\% DPPH.
\end{tabular}

The results showed the total phenol ethanol extract of juwet fruit was 284.47 mg/100g/GAE. Phenol has a toxic and corrosive effect to human skin and at a certain concentrations may cause human health problems and death (Qadeer and Rehan, 1998).

Flavonoids has a conjugated aromatic system which showed a strong absorption band in the UV region. The flavonoid levels obtained was $379.07 \mathrm{mg} / 100 \mathrm{~g}$. Flavonoids act as antioxidants by donating their hydrogen atoms or through their ability to chelate metals, in the form of glucoside (containing glucose side chains) or in the free form called aglycone (Cuppett et al., 1954).
Tannins consist of two types: condensed tannins and hydrolized tannins (Hovath, 1981). The results of this study showed that every $100 \mathrm{~g}$ of the extract contained $3041.60 \mathrm{mg}$ of tannin/100 $\mathrm{g}$ of TAE.Anthocyanin is a water-soluble pigment that naturally accumulates in the epidermal cells of fruits, roots, and leaves. Anthocyanin can replace the use of synthetic carmoisine and amaranth dyes as red dyes in food products. The results of this study showed that every $100 \mathrm{~g}$ of extract containing anthocyanin of $40.28 \mathrm{mg} / 100 \mathrm{~g}$. Anthocyanin acting as antioxidants in the body, makes them atherosclerosis fighters. Anthocyanin also protect the integrity of the endothelial cells 
which lining the walls of blood vessels (Ginting and Sutomo, 2011).

Based on the data in Table 2, a regression equation was obtained as $\mathrm{y}=$ $40.839 x+47.02$ and through this equation was obtained an $\mathrm{IC}_{50}$ value of $72.96 \mu \mathrm{g} / \mathrm{ml}$. This means $72.96 \mu \mathrm{g} / \mathrm{ml}$ ethanolic extract of juwet fruit were able to act as antioxidants to inhibit DPPH (free radicals) by $50 \%$. According to Phongpaichit et al. (2011) category, this $\mathrm{IC}_{50}$ value belongs to the moderate active category. Existing studies revealed that strawberries have an $\mathrm{IC}_{50}$ of $68.03 \mu \mathrm{pm}$ or $68.03 \mu \mathrm{g} / \mathrm{ml}$ (Anggraini et al., 2017) which means the antioxidant of strawberry is almost the same as the juwet fruit. Based on the category, $\mathrm{IC}_{50}$ of $>250$ $\mu \mathrm{g} / \mathrm{ml}$ is classified as not active antioxidant compound, IC $\mathrm{IC}_{50}$ of $100-250 \mu \mathrm{g} / \mathrm{ml}$ as weak, $\mathrm{IC}_{50}$ of $50-100 \mu \mathrm{g} / \mathrm{ml}$ as moderate, and $\mathrm{IC}_{50}$ of $10-50 \mu \mathrm{g} / \mathrm{ml}$ as active antioxidant compound.

\section{CONCLUSIONS}

The juwet fruit grown in Dauh Peken Village-Tabanan contained 284.7 $\mathrm{mg} / 100 \mathrm{~g} / \mathrm{GAE}$ phenol, $379.07 \mathrm{mg} / 100 \mathrm{~g}$ flavonoids, $3888.67 \mathrm{mg} / 100 \mathrm{~g} / \mathrm{TAE}$ tannins, and $40.28 \mathrm{mg} / 100 \mathrm{~g}$ anthocyanin which consisted of 66 types of chemical compounds. The fruit exhibit fairly antioxidant activity with $\mathrm{IC}_{50}$ of $72.96 \mu \mathrm{g} / \mathrm{ml}$. The suggestion for further research is directed to determine the function of unknown compounds contained in juwet fruit.

\section{REFERENCES}

Anggraini, D., A. Fernando, dan N. Elisa. (2017). Formulasi losion antioksidan ekstrak buah stroberi (Fragaria ananassa). Skripsi. Riau. Sekolah Tinggi Ilmu Farmasi.

Chun, K.O., Kim Dae-ok., and Y.C. Lee. (2003). Superoxide radikal scavenging activity of the major polyphenol in fresh plums, Journal Agric. Food Chem, Department of Food Science and Tecnology, Cornell University, Geneva, New York.

Cuppett, S., M. Schrepf, and C. Hall III. (1954). Natural antioxidant-are they reality. Dalam Foreidoon Shahidi: Natural Antioxidants, Chemistry, Health Effect and Applications, Champaign: AOCS Press.

Ghasemi, K., Y. Ghasemi, M. Ebrahimzadeh. (2009). Antioxidant activity, phenol, and flavonoid contents of 13 citrus species peels and tissues. Pak. J. Pharm. Sci., (22).

Ginting, E. and J. S. Utomo. (2011). Anthocyanin and total phenolic contents of purple-fleshed sweet potato cultivars and their antioxidant activity. In B. Kusbiantoro, L.K. Darusman, S. Budianto, and N. Bermawie (Eds.). Proceedings of the International Conference on Nutraceuticals and Functional Foods in Denpasar, Bali on 12-15 October 2010. Indonesian Centre for Rice Research, AARD. Jakarta.

Giusti, M., Monica, and R. E. Wrolstad. (2001). Characteristic and Measurement of Anthocyanin by $U V$ Visible Spectroscopy, Current Protocols in Food Analytical Chemistry.

Horvath. (1981). The Nutritional and ecological significance of acer-tannins 
and related polyphenols. MSc thesis. Cornell University. Ithaca. New York. Lauderback, C. M., J. Drake, D. Zhou, M. Janna Hackett, A. Castegna, J. Kanski, M. Tsoras, S. Varadarajan, and D. A. Butterfield. (2009). Derivatives of xanthic acid are novel antioxidants: Application to Synaptosomes. Free Radical Research, 37(4).

Mayer, A. and M. E. Tanner. (2007). Intermediate release by ADP-Lglycero-D-manno-heptose $6-$ epimerase. Biochemistry (20).

Phongpaichit S., J. Nikom, N. Rungjindamai, J. Sakayaroj. (2011). Biological activities of extracts from endophytic fungi isolated from Garcinia plants. FEMS Immunol. Med. Microbiol.

Primack, R.B., J. Supriatna, dan M. Indrawan. (1998). Biologi Konservasi. Edisi ke dua (rev.). Yayasan Obor Indonesia. Jakarta.

PubChem. (2020). Methyl gamma-linolenate. https://pubchem.ncbi.nlm.nih.gov/ compound/Methyl-gamma-linolenate. (4 Juni 2020).

Putranti, R. Ika. (2013). Skrining fitokimia dan activitas antioksidan ekstrak rumput laut Sargassum duplicatum dan Turbinaria ornate dari Jepara. Magister Thesis. Universitas Diponegoro-Semarang. 